\title{
Neurilemoma of the caruncle: a clinicopathological report
}

\author{
I G Rennie, M A Parsons, M T Benson
}

Abstract
We report a case of a neurilemoma
(schwannoma) arising from the lacrimal

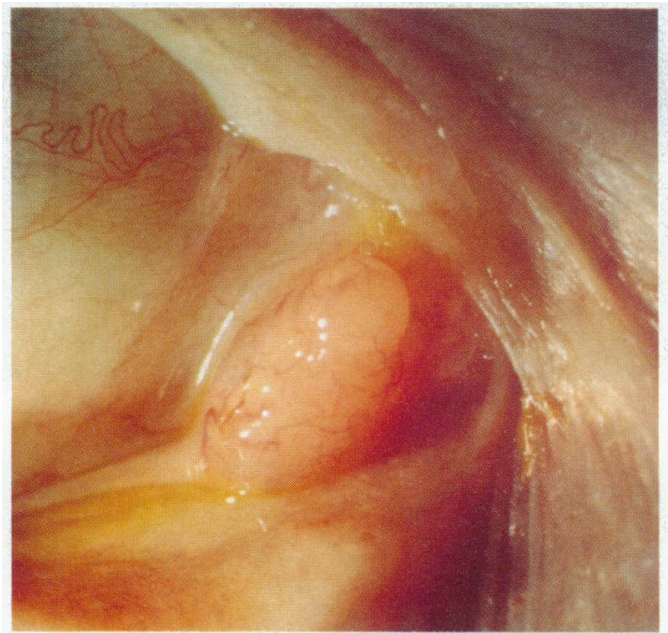

Figure 1 Neurilemoma arising from right lacrimal caruncle. caruncle. The clinical and light and electron microscopic features are described.

Neurilemomas (schwannomas) are benign, encapsulated, slowly progressive tumours that arise from peripheral nerves. They are usually solitary, occur principally between the ages of 20 and 50 years, and have a predilection for the head and neck. ${ }^{1}$ In contrast to neurofibromas, neurilemomas are only occasionally associated with neurofibromatosis. ${ }^{2}$

Neurilemomas account for approximately $1 \%$ of biopsies for orbital tumours. ${ }^{3}$ Intraocular lesions, presumably arising from the ciliary nerves, have been described infrequently. ${ }^{4-7} \mathrm{We}$ describe the clinicopathological appearances of neurilemoma arising from the lacrimal caruncle. To our knowledge this is the first reported case of such a lesion arising from this location.

\section{Case report}

A 75-year-old female presented to the Ophthal-
University of Sheffield

Department of Ophthalmology

I G Rennie

M T Benson

Department of Pathology $M$ A Parsons

Correspondence to:

Mr I G Rennie, Department of Ophthalmology, Royal

Hallamshire Hospital, Glossop Road, Sheffield S10 2JF.

Accepted for publication 7 May 1991

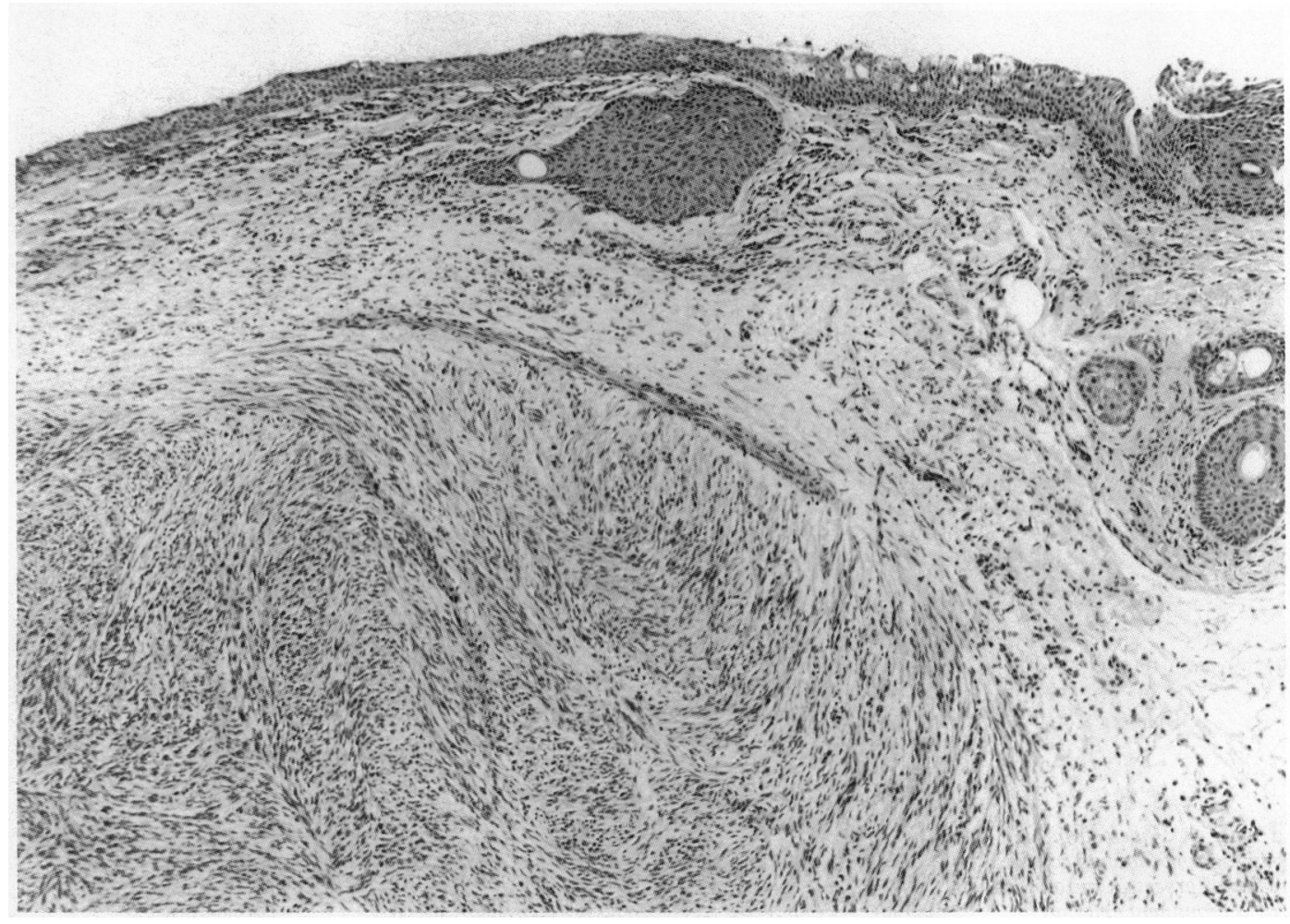

Figure 2 On light microscopy the spindle cell neoplasm lies beneath the epithelium of the caruncle. A hair follicle is present at the right edge of the section. (Haematoxylin and eosin, $\times 160$.) 
Figure 3 Electron micrograph showing numerous complex interdigitating cell processes (right). On the left cellular process (arrow) is wrapped around extracellular collagen to form a pseudomesaxon. $(\times 20000$. $)$

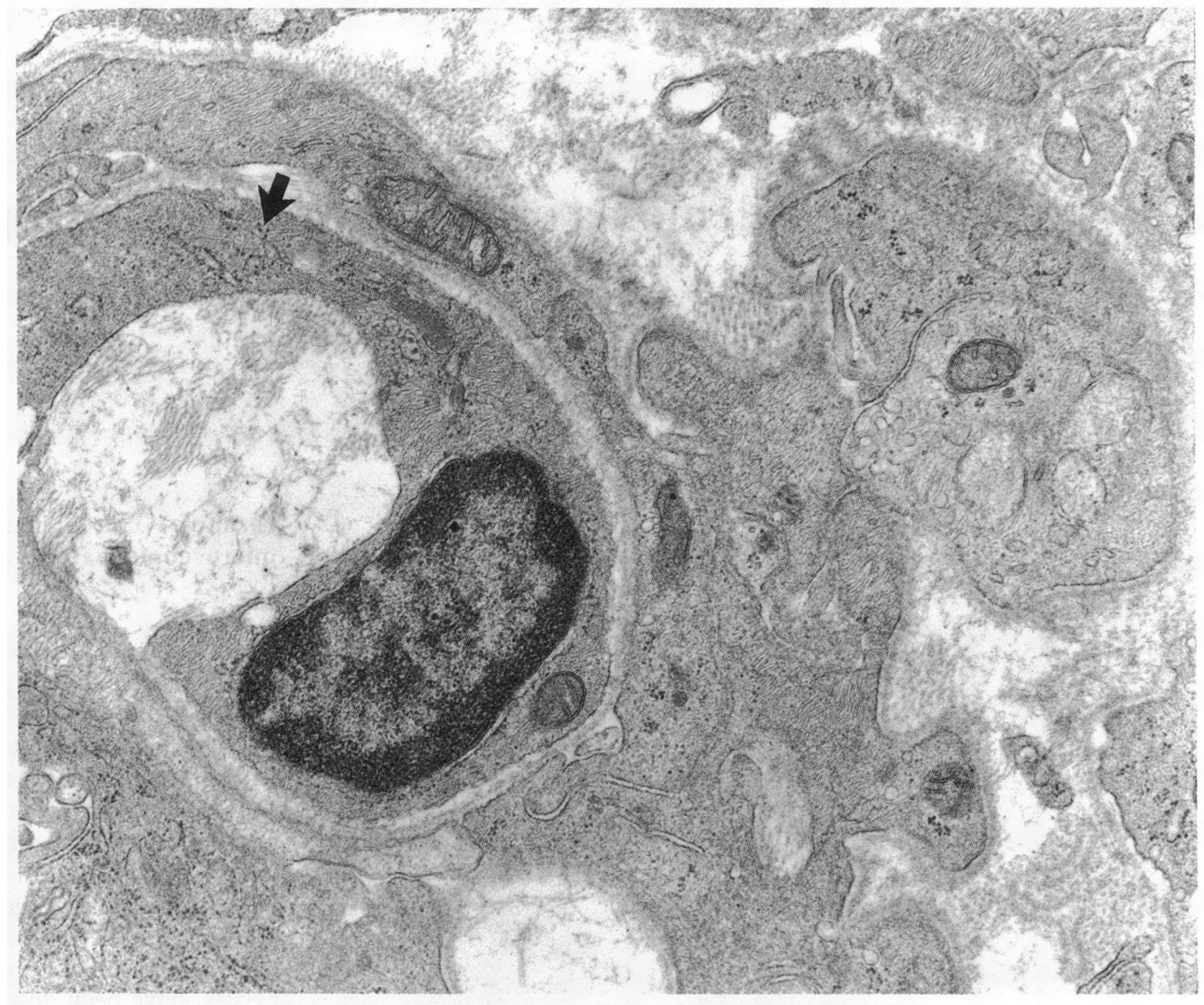

Figure 4 An electron micrograph showing complex cellular processes surrounded by a prominent external lamina (arrow), with some redundant folds. $(\times 57000$. $)$

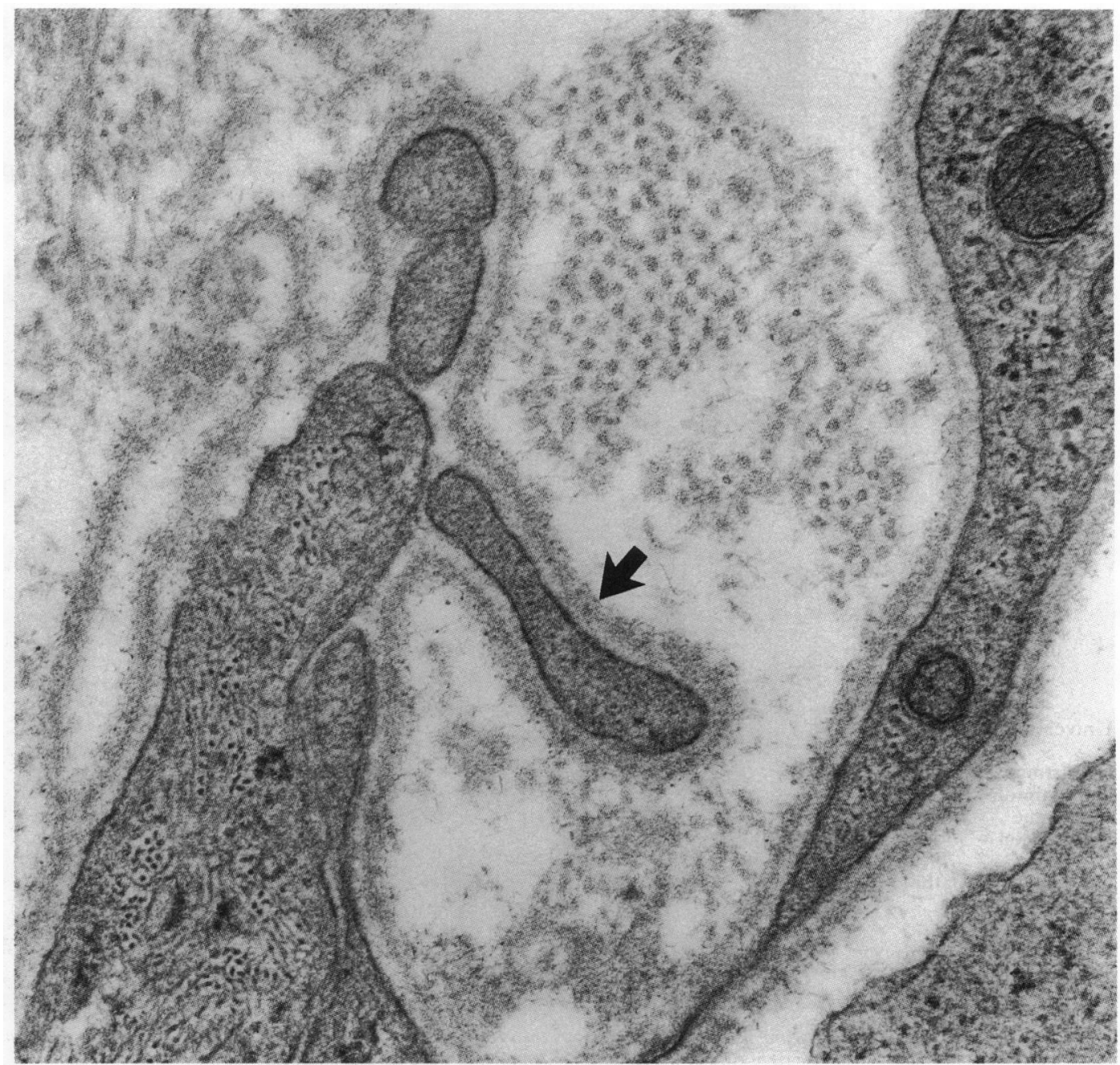


mology Department with a swelling arising from the right lacrimal caruncle. The patient was uncertain as to how long the lesion had been present. There was no significant ophthalmic history or evidence of neurofibromatosis. She had recently been diagnosed as suffering from an inoperable carcinoma of the pancreas.

On examination her best corrected visual acuities where right eye $6 / 12$, left $6 / 12$. A small, fleshy, oval lesion measuring approximately $6 \times 4 \times 4 \mathrm{~mm}$ was noted arising from the right lacrimal caruncle (Fig 1). The rest of the ocular examination gave normal results apart from pseudoexfoliation in the left eye and bilateral, mild, age-related macular changes. The lesion was removed under local anaesthetic. Her postoperative progress was uneventful.

\section{HISTOLOGICAL EXAMINATION}

Macroscopic findings. The specimen consisted of a smooth lobulated yellow lesion measuring $6 \times 4 \times 4 \mathrm{~mm}$, which on sectioning was encapsulated and had a homogeneous yellow cut surface.

Microscopic findings. On light microscopy there was a spindle cell neoplasm beneath the epithelium and hair follicles of the lacrimal caruncle (Fig 2). The tumour had a central cellular area, with a more myxoid peripheral zone of low cellularity. It was slightly fasiculated, but nuclear palisading was absent. Mitotic figures were not seen.

On electron microscopy the spindle shaped tumour cells had numerous complex interdigitating processes; in some cells these processes wrapped around extracellular collagen to form pseudomesaxons (Fig 3). The cells had a prominent external lamina with some redundant folds (Fig 4). Luse bodies of long-spacing collagen and occasional proteoglycan particles were present in the intercellular matrix. The electron microscopic appearances were characteristic of a neurilemoma (schwannoma), ${ }^{8}$ and the light microscopic features were those of a benign neurilemoma.

\section{Discussion}

The lacrimal caruncle is a piece of modified skin, covered by stratified squamous epithelium and containing hair follicles, sebaceous glands, and sweat glands. ${ }^{9}$ It is innervated by a branch of the infratrochlear nerve. Neurilemomas arise as proliferations from the peripheral nerve sheath, and presumably this lesion developed from one of the terminal branches of the infratrochlear nerve.

Lesions of the lacrimal caruncle are relatively rare. In a review of $\mathbf{4 0 0 0 0 ~ o p h t h a l m i c ~ p a t h o l o g y ~}$ specimens Luthra et al found only $112(0 \cdot 28 \%)$ lesions affecting the caruncle. ${ }^{10}$ Shields et al reviewed over 18000 pathology reports and found only 57 involving caruncle. ${ }^{11}$ In these two studies papillomas and naevi accounted for over half the total lesions. Neither study identified a lesion arising from a peripheral nerve. Similarly, earlier reports by Evans, ${ }^{12}$ Wilson, ${ }^{13}$ and Serra ${ }^{14}$ failed to identify a tumour of peripheral nerve as a cause of a caruncular lesion. It would appear that neurilemomas represent a rare and until now unreported form of caruncular tumour.

1 Rootman J. Disease of the orbit. Philadelphia: Lippincott, 1988.

2 Shields JA. Diagnosis and management of orbital tumors. Philadelphia: Saunders, 1989

3 Shields JA, Bakewell B, Augsburger JJ, et al. Classification and incidence of space occupying lesions of the orbit. Arch phthalmol 1984; 102: 1606-11

4 Shields JA, Sanborn GE, Kurz GH. Benign peripheral nerve tumor of the choroid: a clinicopathological correlation Ophthalmology 1981; 88: 1322-9.

5 Rosso R, Colombo R, Ricevuti G. Neurilemmoma of the ciliary body: report of a case. BrF Ophthalmol 1983;67: 5857.

6 Smith PA, Damato BE, Ko MK, Lyness RW. Anterior uveal neurilemmoma - a rare neoplasm simulating malignant melanoma. Brf Ophthalmol 1988; 71: 34-40.

7 Freedman SH, Elner VM, Donev I, Gunta R, Albert DM. Intraocular neurilemmoma arising from the posterior ciliary nerve in neurofibromatosis. Ophthalmology 1988; 95: 155964.

8 Ghadialli FN. Diagnostic electron microscopy of tumours. London: Butterworths, 1985

9 Wolff E. Anatomy of the eye and orbit. Philadelphia: Saunders, 1986.

10 Luthra CL, Doxanas MT, Green WR. Lesions of the caruncle a clinicopathologic study. Surv Ophthalmol 1978; 23: 183-

11 Shields CL, Shields JA, White D, Augsburger JJ. Types and frequency of lesions of the caruncle. Am F Ophthalmol 1986; 102: 771-8.

12 Evans WH. Tumors of the lacrimal caruncle: a study of two hundred collected cases. Arch Ophthalmol 1940; 24: 83-106. Wilson RP. Tumours and cysts of the lacrimal caruncle. Trans Ophthalmol Soc N Z 1958;11: 23-32.

14 Serra GM. Tumori della caruncula lacrimale. Studio clinico anatomo pathologicocasista. Boll Oculist 1928; 7: 783-820. 